Available online: https://journals.researchsynergypress.com/index.php/ijebce/

International Journal of Entrepreneurship, Business and Creative Economy (IJEBCE)

ISSN 2775-3085 (Online) | 2775-3107 (Print)

Volume 2 Number 1 (2022): 23-36

\title{
Impact of Social Media On Consumer Purchase Behaviour During COVID- 19 Pandemic
}

\author{
Lim Kah Boon', Sook Fern Yeo', Cheng Ling Tan², Wong Wei Wen' \\ ${ }^{1}$ Faculty of Business, Multimedia University Melaka, Malaysia \\ ${ }^{2}$ Graduate School of Business, University Sains Malaysia, Penang, Malaysia
}

\begin{abstract}
Social media has been used by people to create and share content with the public. Consumers have changed their purchasing habits from offline to online purchases during the COVID-19 pandemic. Social media is also changing sellers' and buyers' specialised strategies. This study aimed to study the factors influencing consumer purchasing behaviour via social media during the COVID-19 outbreak. 215 young adults from three Malaysian states which are Johor, Melaka, and Selangor, have been invited to participate in this study by answering a set of questionnaires. The successful response rate is $93.02 \%$, where 200 completed questionnaires were used for data analysis in this study. The four independent variables, price, convenience, product variety, and risk, are tested in relation to the dependent variable, consumer purchase behaviour during the COVID-19 outbreak. The measurement items of all the four independent variables and dependent variables were adopted from the past research studies. The collected data were entered into SPSS version 26 and then tested using Partial Least Square Structural Equation Modelling (PLS-SEM 3.3.3). All hypotheses were found to be supported by the analysis results. Lastly, the findings of this study will help marketers understand consumer purchasing behaviour via social media during the COVID-19 pandemic.
\end{abstract}

Keywords: Convenience; COVID-19; Price; Product variety; Purchase behaviour; Risk

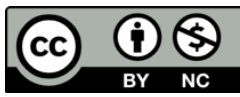

This is an open access article under the CC-BY-NC license.

\section{INTRODUCTION}

Technological advancement has resulted in the rapid development of the Internet, as well as increased the Internet's acceptance of social interaction and global use of social media. Social media can be defined as "consumer-created media that covers a wide range of new wellsprings of online data, created and utilised by consumers' determined to share any data of interest to others" (Kohli et al., 2015). As of January 2020, approximately 81 percent of Malaysians were active social media users (Joschka, 2021). It has increased by about one-third since 2016. In 2016, social media users accounted for approximately $60 \%$ of Malaysia's total population (Joschka, 2021). According to these statistics, social media has evolved into an important medium for businesses to communicate with their audiences and increase revenue.

The sale and purchase of goods and services via the Internet are referred to as Internet commerce (Keeney, 1999). Businesses and consumers can interact and conduct business transactions electronically because the internet makes it easier, simpler, less expensive, and more accessible. The internet's technology has facilitated transactions, reduced costs, expanded product offerings, and improved user convenience. Business people can easily meet with their potential 
International Journal of Entrepreneurship, Business and Creative Economy (IJEBCE), Vol. 2(1), 23-36 Impact of Social Media On Consumer Purchase Behaviour During COVID-19 Pandemic Lim Kah Boon, Sook Fern Yeo, Cheng Ling Tan, Wong Wei Wen

customers on social media platforms (Surenderkumar, 2016). The Internet is altering the nature of consumer purchasing behaviour and offers numerous advantages over traditional shopping delivery channels. The Internet is also viewed as a major threat to traditional retail stores. These advancements have greatly benefited customers and influenced their purchasing habits.

Furthermore, the COVID-19 pandemic, which occurred unexpectedly in the year 2020, influenced the majority of people to change their purchasing behaviour via social media. It is because they are unable to go out and purchase necessities such as daily goods and food. As a result, the COVID-19 pandemic had an indirect impact on consumer habits, shifting them from traditional to online retail stores. According to the research, 52 percent of consumers avoid going physical shopping and congested areas. People are avoiding going out and maintaining social distance, and most people prefer to buy and work from home (Bhatti et al., 2020). Furthermore, 36 percent are keeping a strategic distance from physical shopping until they get a vaccine against COVID-19 (Bhatti et al., 2020). Consumers' purchasing habits are influenced by online businesses. Communication via social media is another stage for exchanging data about products and services (Surenderkumar, 2016).

Social media has evolved into an important medium for presenting market products and conducting product reviews. Social media is now an important promotion tool in the marketing field. As a result, it is critical to understand how social media influences consumer purchasing behaviour. Furthermore, customers can access the social media platform at any time and from any location to view and purchase products or services. Consumers can use the internet whenever they want because it is available 24 hours a day, seven days a week. Online users have started to form social connections with the brand. In this sense, in order to gain a competitive advantage, the company must comprehend the needs, characteristics, and relationships of such consumers. Nowadays, various social networking sites are sprouting up in such a way that customers can purchase goods online at any time. Most likely, income has increased on the internet in comparison to previous years.

Because of the high level of competition in social media, it is valuable and sufficient to obtain and investigate purchase behaviour through social media. The likelihood of a consumer purchasing a specific product is referred to as purchasing behaviour. Consumers' choices are influenced by a wide range of factors. Marketers are closely monitoring consumer use of social media, but little is known about how it influences consumer decision-making. Numerous studies have been conducted on consumer behaviour in the online shopping environment, but none have considered the effects of social media on the various stages of the decision-making process (Darley et al., 2010). The goal of this study is to analyse consumers' purchase intentions via social media. In other words, this study is founded not only on surveys but also on the relationship and structural status of online consumers in social media.

\section{LITERATURE REVIEW}

\section{Purchase Behaviour on Social Media}

Purchase behaviour revealed information about the product's flavour and the likelihood of purchase. The purchase behaviour has been announced, which can be used to estimate consumer behaviour (Haque et al., 2015). The purpose of consumers participating in online purchases via social networking sites is defined as purchasing intention (Hussain et al., 2021). Purchase 
International Journal of Entrepreneurship, Business and Creative Economy (IJEBCE), Vol. 2(1), 23-36 Impact of Social Media On Consumer Purchase Behaviour During COVID-19 Pandemic Lim Kah Boon, Sook Fern Yeo, Cheng Ling Tan, Wong Wei Wen

behaviour is defined as a series of choices made by a consumer prior to making a purchase, which begins when they are eager to satisfy a need (Hanaysha, 2018). Online purchasing is when consumers use the internet as a channel to directly purchase products and services from the vendor, and it is a type of internet business in which consumers do not need to use any intermediary services to purchase anything (Rizwan et al., 2014). Furthermore, consumer recognition in social network sites can enable consumers or online purchasers to look and do product or service correlation in the middle of various online stores regardless of where the store or online shop is situated in the world. In general, purchase behaviour refers to a consumer's willingness to purchase an item from a mall or from a website, as well as their observations and desires regarding the item. Furthermore, it is defined as whether the item worth purchasing will also influence the customer to purchase a similar item from a marketplace. The researchers demonstrated that purchase behaviour is typically related to a consumer's behaviour, perceptions, and attitudes (Mirabi et al., 2015). As a result, purchase behaviour had a consistent relationship with consumer behaviour, which is their perspectives, attitudes, and awareness.

Previous research has shown that the purchaser will discover what products they need to buy and then look through the insights to evaluate the product, assess, and finally purchase and provide feedback (Rahim et al., 2016). This can imply that a buyer will buy a product after conducting research to ensure that they get the right product for their wants and needs (Rahim et al., 2016). In most cases, consumer purchasing behaviour to make a decision is extremely unpredictable. Purchase behaviour may be influenced by a lower price or superior quality and value of the goods (Mirabi et al., 2015). Consumers frequently choose to purchase a product based on a variety of factors, such as whether the stores provided better service to them or not, whether the products and services provided are worth the price charged by the stores, whether the products are durable and meet the expectations of the consumers, or whether the store provides incentives or promotions to the purchaser. Because a large percentage of consumers are concerned about product quality, sellers must constantly improve and advance their products in order to attract and retain customers. As a result, it may help the company improve its image and establish a competitive advantage over competitors. All of these factors will have an impact on consumer purchasing behaviour because people nowadays are looking for things that will allow them to live a better life.

\section{Price}

Price is the amount of money that a consumer is willing to pay for a product or service or the total amount of money that a consumer exchanges for ownership of the product or service (Kotler \& Armstrong, 2016). Price is a measure of cash expected, required, or given in installments for trade with a product or service that they thought was significant (Lay-Yee et al., 2013). According to Kim et al. (2005), the target value denotes the total amount that consumers must pay for a product, whereas the reference value denotes the amount that consumers intend to pay for the product. The apparent cost of the channel may influence consumers' purchasing decisions (Chiang \& Dholakia, 2003). According to Reibstein (2002), online consumers generally seek price information from various retailers for a similar item in order to make the most advantageous financial decision. Price is the most delicate component of the market mix and the primary component that generates pay. Price can be considered as one of the important criteria that influence a buyer's decision to 
International Journal of Entrepreneurship, Business and Creative Economy (IJEBCE), Vol. 2(1), 23-36

Impact of Social Media On Consumer Purchase Behaviour During COVID-19 Pandemic

Lim Kah Boon, Sook Fern Yeo, Cheng Ling Tan, Wong Wei Wen

purchase. In any case, price can be controlled, and many organisations place a premium on this aspect (Hustic \& Gregurec, 2015).

Companies can comprehend the critical features of product attributes that influence consumer behaviour, such as brand and price. Price is an important variable in social media because it influences consumers' purchasing decisions when they are purchasing a product. When used as a heuristic signal, researchers found that price is more effectively detectable than quality (Yoon et al., 2014). Some customers may choose to buy a product based on price, but for many others, the value relative to quality is extremely important.

Aside from that, the price will be able to influence consumer purchasing behaviour, particularly through social media. The reason for this is that price is one of many factors that influence the decision to purchase a product. Clemes et al. (2014) discovered a positive relationship between price and purchasing behaviour. Because the price is regarded as a significant factor in marketing methodologies, a few organisations will employ unique pricing models to increase consumer purchasing behaviour (Lin et al., 2013). Guo and Barnes (2011) stated that there is a significant relationship between price and purchase behaviour. According to previous research, the author discovered that price has a significant influence on purchasing behaviour (Lay-Yee et al., 2013). Aside from that, researchers stated that consumer product knowledge has a significant impact on purchase behaviour when compared to price (Lin et al., 2012). According to Lin et al. (2009), price promotion causes consumers to have doubts when evaluating a product. A high price promotion will result in a low perceived quality of the product, influencing consumer purchasing behaviour. As a result, there is no statistically significant relationship between price and purchasing behaviour (Lin et al., 2009).

H1: There is a significant relationship between price and consumers' purchase behaviour through social media during the COVID-19 Pandemic.

\section{Convenience}

Convenience has been linked to the choice of non-store shopping situations, such as social networking sites (Darian, 1987). Convenience implies that customers can save time and effort when shopping on social networking sites. Saving time and effort is part of the overall convenience structure of shopping (y Monsuwé et al., 2004). Most consumers credit social media platforms with convenience and availability because they can shop online in the comfort of their own home, saving time and effort, and shopping at any time of day or night (y Monsuwé et al., 2004). Shopping convenience is widely acknowledged to be a significant motivating factor in consumers' decisions to purchase items at home (Clemes et al., 2014). The researcher identified five types of convenience for in-home shopping. Its advantages include reduced shopping time, timing adaptability, avoiding the physical exertion of visiting a traditional store, avoiding disruption, and allowing for impulse purchases or legitimately reacting to an advertisement (Darian, 1987).

The social media platform eliminated the need for consumers to drive and check out while also allowing them access to distant stores. Several studies have shown that convenience was a significant motivator for the creation of social networking sites. The researcher also concludes that consumer online purchasing behaviour is positively related to convenience (Meuter et al., 2000). Furthermore, researchers proposed that consumers' perceptions of convenience have a positive 
International Journal of Entrepreneurship, Business and Creative Economy (IJEBCE), Vol. 2(1), 23-36 Impact of Social Media On Consumer Purchase Behaviour During COVID-19 Pandemic Lim Kah Boon, Sook Fern Yeo, Cheng Ling Tan, Wong Wei Wen

impact on their willingness to make Internet purchases and patronise Internet retail stores (Swaminathan et al., 1999). Consumers' perceptions of convenience have a significant impact on their willingness to make Internet purchases and support Internet retail stores. Because consumers gain utilitarian value from efficient and timely transactions, time and effort savings have a significant impact on customers' online purchasing behaviour (Childers et al., 2001).

Online retailers must ensure that social media platform measurement is simple and straightforward, as well as that maximum customization is provided (Lohse et al., 2000). According to past research, both value-added and diversion data should be combined with online stores that encourage consumers to use social media platforms. From a convenience standpoint, some consumers use social media platforms to avoid up close and personal communication with salespeople because they feel pressured or awkward when managing sales reps and have no desire to be controlled in the marketplace (Goldsmith \& Flynn, 2005). Szymanski and Hise (2000) also concluded that purchaser perceptions of social network site convenience, variety of product offerings and product data, and financial security play an important role in e-fulfillment. According to the findings of the study, convenience has a strong relationship and a statistically significant positive effect on social network site receptivity (Akbar and James, 2014). The findings of a previous study revealed that the most common factors influencing consumers' online purchasing behaviour are convenience, price, a wider range of options, and service quality (Delafrooz et al., 2009). It had a positive impact on consumers' online purchasing behaviour and demonstrated that as social media platforms become more convenient and time-saving, consumers' opposition will decrease (Beneke et al., 2010).

H2: There is a significant relationship between convenience and consumers purchase behaviour through social media during the COVID-19 Pandemic.

\section{Product Variety}

According to Keeney (1999), product variety is a wide range of items that prompts better comparison and, as a result, a better purchase decision. The goal of product design and manufacturing is to meet the perceived needs of consumers. As a result, a variety of products are developed to meet the needs of various consumers. Variety is defined as the number or collection of different things in a specific category within the same general category (ElMaraghy et al., 2013). The concept of variety applies to both products and services. The manufacturer will seek to gain more benefits and increase consumer value by offering more options, differentiated features and functions of products and services, and opportunities for customization and even personalization (ElMaraghy et al., 2013). The availability of a wide range of products is one of the primary reasons why people shop online. According to Bakos (1997), there are several reasons why online consumers care about product variety. First, superior assortments can increase the likelihood that their needs will be met, especially if the item is likely to be unavailable from traditional retail stores. Second, a larger grouping with a more refined search engine would enable buyers to purchase higher-quality items (Bakos, 1997).

Cho (2004) stated that having a wide range of products available online means having access to more information, which leads to more rational purchasing behaviour and a higher level of fulfillment. Consumers' perceptions of assortment are influenced not only by the number of 
International Journal of Entrepreneurship, Business and Creative Economy (IJEBCE), Vol. 2(1), 23-36

Impact of Social Media On Consumer Purchase Behaviour During COVID-19 Pandemic

Lim Kah Boon, Sook Fern Yeo, Cheng Ling Tan, Wong Wei Wen

distinct items but also by reiteration frequency, presentation association, and property contrasts (Hoch et al., 1999). As a result of the research, online consumers have a more positive perception of the product variety of online shopping than non-online shopping consumers ( $\operatorname{Sin} \&$ Tse, 2002). Consumers typically prefer a greater variety of options. A variety of product contributions and unique product contributions are recognised as a significant positive practical impact legitimately identified with social media platforms (Cho, 2004). The researchers discovered that, when compared to non-online consumers, online consumers have a more certain assessment of the product variety available through social media (Sin \& Tse, 2002). Thus, Clemes et al. (2014) proposed that there is a significant relationship between product variety and consumer purchase behaviour through social media.

Most of the consumers are motivated by a scope of choices from sellers and brands available through social media. Another significant study discovered that when products were organised into more subcategories in the choice menu, consumers saw that the social network sites offered a more significant assortment of products and experienced greater shopping delight, which improved their purchasing behaviour toward the social media (Chang, 2011). The researches revealed that online sellers with a wide variety of product categories would, in general, profit more to the online buyer (Mallapragada et al., 2016). H3: There is a significant relationship between product variety and consumers purchase behaviour through social media during the COVID-19 Pandemic.

\section{Risk}

Risk is defined as the inability of consumers to genuinely check the quality of an item or monitor the safety and security of sending personal and financial information while shopping online (Lee and Turban, 2001). Risk also refers to the consumers' perception of the vulnerability and unfavourable outcomes of the activities (Mahliza, 2020). The level of risk that consumers believe is associated with purchasing a product from a specific seller was indicated by risk (Mahliza, 2020). Internet shopping, as a type of business activity, entails more vulnerability and risk than traditional shopping. Consumers are less aware of online stores. Furthermore, consumers cannot truly assess the quality of products before purchasing them, nor can they assess the safety and security of sending sensitive personal and financial data, such as credit card numbers, over the Internet to a party whose practices and intentions may be difficult to predict (Lee \& Turban, 2001).

With regard to social media platforms, the risk is an applicable situational boundary in that (1) there is a vulnerability about the outcome of an Internet shopping transaction, (2) the outcome is dependent on the conduct of the Internet dealer, which is outside the purchaser's domain and control, and (3) the consequences of an unfavourable outcome may outweigh the benefits of a favourable outcome (Lewicki \& Bunker, 1995).

Risk propensity is based on risk sources, and online activity is a risk source for people. Risk proclivity is related to the ability to anticipate risk (Cases, 2002). Risk propensity refers to the activity stage that occurs after the decision to take or avoid risk and is viewed by some scholars as the result of perspectives and recognitions influencing individual activities or behaviour (Liu et al., 2005). Risk can be viewed as a form of non-monetary penance. If the proportional estimation of social media platforms remains constant, this implies that an increase in consumers' risk observation will reduce procurement utility. Furthermore, risk refers to the non-monetary 
International Journal of Entrepreneurship, Business and Creative Economy (IJEBCE), Vol. 2(1), 23-36 Impact of Social Media On Consumer Purchase Behaviour During COVID-19 Pandemic Lim Kah Boon, Sook Fern Yeo, Cheng Ling Tan, Wong Wei Wen

component of transaction utility, according to mental accounting theory. A rise in risk reduces transaction utility. As a result, risk should have a negative impact on value (Shimp \& Bearden, 1982).

Understanding consumer risk and how consumers respond to and mitigate risk can help supervisors improve their business opportunities and methodologies (Comegys et al., 2006). Risk can be represented in a variety of ways in an electronic shopping environment. The researchers divide risk into five categories: economic, social, performance, performance, and privacy (Jarvenpaa \& Todd, 1996). In the context of specific risks, the researchers discovered that the risk associated with not receiving what is expected and financial card issues might have a negative impact on consumers' online purchasing behaviour (Bhatnagar et al., 2000). Researchers stated that there is a negative relationship between risk and consumers' purchase behaviour through social media platforms (Clemes et al., 2014). Researchers also looked into a few specific studies with regard to the predecessors of social media platforms and concluded that risk had a negative effect on consumers' purchase behaviour via social media (Chang et al., 2005). Furthermore, customers are more likely to shop at online stores that have strong security and privacy safeguards.

H4: There is a significant relationship between risk and consumers' purchase behaviour through social media during the COVID-19 Pandemic.

\section{RESEARCH METHOD}

This study employed convenience sampling in the data collection process. The minimum required sample size based on the $\mathrm{G}^{*}$ power calculation is 129 respondents. 215 targeted respondents in three states of Malaysia which includes Johor, Melaka, and Selangor have been invited to participate in this study by filling up the questionnaire via Google form. The completed 200 sets of questionnaires are used for data analysis purposes in this study, and this contributes to a successful response rate of $93.02 \%$. There are three main sections in the set of a self-administered questionnaire, which covered demographic variables the measurement items for independent and dependent variables. All of the measurement items of independent variables are adopted from Clemes et al. (2014), and the items of the dependent variable are adopted from Hanaysha (2018). A five-point Likert scale ( $1=$ strongly disagree to $5=$ strongly agree) is applied in this study. SPSS version 26 and Partial Least Square Structural Equation Modelling (PLS-SEM 3.3.3) are used for data analysis purposes in this study. Partial Least Squares Structural Equation Modelling (PLS-SEM) has been applied in many disciplines of research. Hair et al. (2014) mentioned that PLS is a composite-based approach to SEM where it aims to maximise the explanation on the variance of dependent constructs in the path model.

\section{FINDINGS AND DISCUSSION}

The demographic profile of 200 respondents is summarised in Table 1. There is a total of 200 respondents involved in this questionnaire, and 73 (36.5\%) are male, while 127 (63.5\%) are female. The majority of the respondents' ages range from 25 to 31 years old. $51.5 \%$ or 103 respondents of this study have a degree education level. The average monthly salary of the respondents involved in this study is between RM2001 to RM3999. 
International Journal of Entrepreneurship, Business and Creative Economy (IJEBCE), Vol. 2(1), 23-36 Impact of Social Media On Consumer Purchase Behaviour During COVID-19 Pandemic Lim Kah Boon, Sook Fern Yeo, Cheng Ling Tan, Wong Wei Wen

Table 1: Respondents' profile

\begin{tabular}{lcc}
\hline Demographic profile & Frequency & Percentage \\
\hline Gender & 73 & 36.5 \\
Male & 127 & 63.5 \\
Female & & \\
\hline Age & 80 & 40 \\
$18-24$ years old & 84 & 42 \\
$25-31$ years old & 21 & 10.5 \\
$32-38$ years old & 13 & 6.5 \\
$39-48$ years old & 2 & 1.0 \\
49 years old and above & & \\
\hline Education level & 20 & 10 \\
Secondary School & 62 & 31 \\
Diploma & 103 & 51.5 \\
Degree & 13 & 6.5 \\
Postgraduate & 2 & 1 \\
Others & & \\
\hline Monthly income level & 66 & 33 \\
Below RM2000 & 81 & 40.5 \\
RM2001 - RM3999 & 44 & 22 \\
RM4000 - RM5999 & 8 & 4 \\
RM6000 - RM7999 & 1 & 0.5 \\
RM8000 and above & & \\
\hline
\end{tabular}

The convergent validity measurement of all the measurement items have to be tested before the Structural Equation Modelling is applied. Table 2 summarises the convergent validity analysis result. The analysis result showed that all the item loadings are range from 0.735 to 0.886 . All item loadings have achieved the minimum requirement (Chin, 1998). Besides that, the composite reliability (CR), Rho_A, and average variance extracted (AVE) values for all the five variables were meeting the requirement too. A strong valid model should have covered the AVE values above 0.5 , CR, and Rho_A values above 0.7 (Hair et al., 2016). Hence, we can conclude that the model constructs have met the convergent validity and internal consistency. Next, the discriminant validity result is presented in Table 3. All the Heterotrait- Monotrait (HTMT) criteria were lower than the required threshold value of HTMT 0.90 by Gold et al. (2001). Hence, this indicates that the proposed hypotheses are supported.

Table 2: Convergent Validity Assessment

\begin{tabular}{|c|c|c|c|c|c|c|}
\hline $\begin{array}{r}\text { Model } \\
\text { construct }\end{array}$ & Items & Loadings & AVE & CR & $\mathrm{CA}$ & Rho_A \\
\hline \multirow{3}{*}{ Convenient } & $\mathrm{C} 1$ & 0.819 & 0.640 & 0.842 & 0.719 & 0.724 \\
\hline & $\mathrm{C} 2$ & 0.776 & & & & \\
\hline & C3 & 0.804 & & & & \\
\hline \multirow{2}{*}{ Price } & $\mathrm{P} 4$ & 0.812 & 0.722 & 0.838 & 0.619 & 0.641 \\
\hline & P5 & 0.886 & & & & \\
\hline \multirow{3}{*}{$\begin{array}{l}\text { Purchase } \\
\text { behaviour }\end{array}$} & PB2 & 0.768 & 0.586 & 0.850 & 0.764 & 0.766 \\
\hline & PB3 & 0.735 & & & & \\
\hline & PB4 & 0.758 & & & & \\
\hline
\end{tabular}


International Journal of Entrepreneurship, Business and Creative Economy (IJEBCE), Vol. 2(1), 23-36 Impact of Social Media On Consumer Purchase Behaviour During COVID-19 Pandemic Lim Kah Boon, Sook Fern Yeo, Cheng Ling Tan, Wong Wei Wen

\begin{tabular}{cllllll} 
& PB5 & 0.800 & & & & \\
\hline \multirow{2}{*}{ Product } & PV1 & 0.839 & 0.643 & 0.844 & 0.723 & 0.734 \\
variety & PV2 & 0.742 & & & & \\
\hline \multirow{4}{*}{ Risk } & PV3 & 0.821 & & & & \\
& R1 & 0.796 & 0.670 & 0.910 & 0.877 & 0.879 \\
& R2 & 0.816 & & & & \\
& R3 & 0.848 & & & & \\
\hline
\end{tabular}

Table 3: Discriminant Validity of Constructs

\begin{tabular}{cccccc}
\hline & Convenient & Price & $\begin{array}{c}\text { Product } \\
\text { variety }\end{array}$ & $\begin{array}{c}\text { Purchase } \\
\text { behaviour }\end{array}$ & Risk \\
\hline Convenient & & & & & \\
\hline Price & 0.889 & & & & \\
\hline $\begin{array}{c}\text { Product } \\
\text { variety }\end{array}$ & 0.839 & 0.710 & & & \\
\hline $\begin{array}{c}\text { Purchase } \\
\text { behaviour }\end{array}$ & 0.796 & 0.811 & 0.833 & 0.676 & \\
\hline Risk & 0.627 & 0.589 & 0.766 & & \\
\hline
\end{tabular}

Next, SMART-PLS bootstrapping was used to measure the structural model. The R2 value of the model is 0.525 , which indicates that $52.5 \%$ of the total variation in purchase behaviour can be explained by the four independent variables. Figure 1 illustrates the overview of the model in this study. Table 4 summarises the hypothesis testing result of this study.

Table 4: Results of the Hypothesis Testing

\begin{tabular}{ccccccc}
\hline Relationship & Std Beta & Std Error & t-value & LL & UL & Decision \\
\hline $\begin{array}{c}\text { Convenient -> } \\
\text { Purchase behaviour }\end{array}$ & 0.191 & 0.090 & $2.111^{*}$ & -0.03 & 0.355 & Supported \\
\hline $\begin{array}{c}\text { Price -> Purchase } \\
\text { behaviour }\end{array}$ & 0.236 & 0.064 & $3.698^{* *}$ & 0.105 & 0.350 & Supported \\
\hline $\begin{array}{c}\text { Product variety -> } \\
\text { Purchase behaviour }\end{array}$ & 0.282 & 0.087 & $3.253^{* *}$ & 0.131 & 0.465 & Supported \\
\hline $\begin{array}{c}\text { Risk -> Purchase } \\
\text { behaviour }\end{array}$ & 0.184 & 0.067 & $2.729^{* *}$ & 0.054 & 0.310 & Supported \\
\hline
\end{tabular}

${ }^{* *} \mathrm{p}<0.01,{ }^{*} \mathrm{p}<0.05$, Bootstrapping $(\mathrm{n}=5000)$

The hypotheses result concluded that all of the four hypotheses are supported at the 5\% significance level. The findings of this study are consistent with the majority of the past studies. Convenience is defined as the ability of consumers to save time and effort when purchasing on a social networking site. Saving time and effort is part of the overall shopping convenience structure (y Monsuwé et al. 2004). Several studies have shown that convenience was a significant motivator 
International Journal of Entrepreneurship, Business and Creative Economy (IJEBCE), Vol. 2(1), 23-36 Impact of Social Media On Consumer Purchase Behaviour During COVID-19 Pandemic Lim Kah Boon, Sook Fern Yeo, Cheng Ling Tan, Wong Wei Wen

for the creation of social networking sites. The researcher also concluded that consumer online purchasing behaviour is positively related to convenience (Meuter et al., 2000). Previous research has also discovered that convenience has a strong relationship and a statistically significant positive effect on social network site receptivity (Akbar \& James, 2014). Furthermore, it had a positive impact on consumers' online purchasing behaviour and demonstrated that as social media platforms become more convenient and time-saving, consumers' opposition will decrease (Beneke et al., 2010).

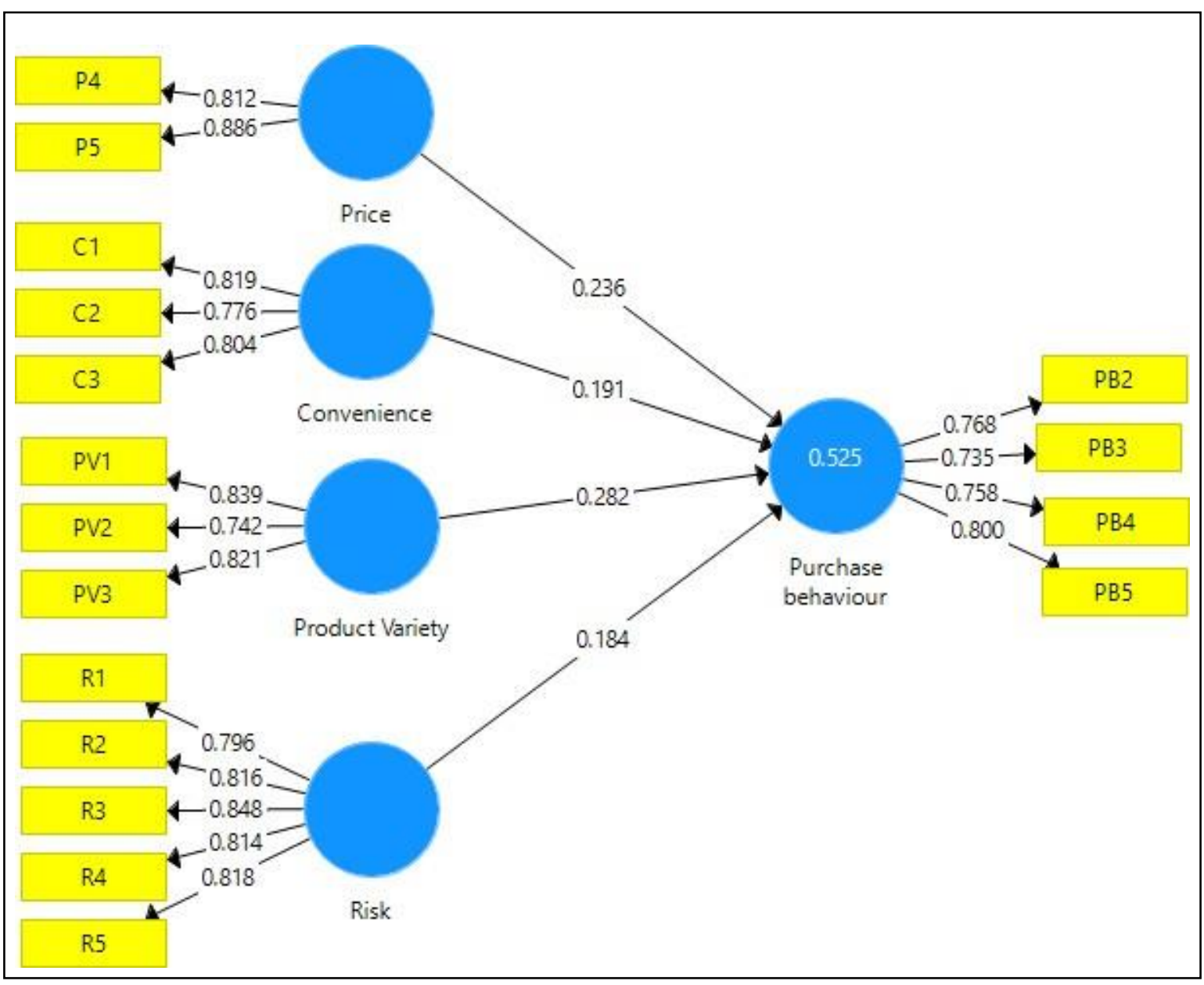

Figure 1: Overview of the Model

Kotler and Armstrong (2016) also showed that price has a significant relationship with purchase behaviour. Yoon et al. (2014) declared that price is more effectively detectable than quality when price is a heuristic signal. As a result, our findings are consistent with previous research. According to previous research, the price has a significant influence on purchasing behaviour. (Lay-Yeeet al., 2013). Furthermore, the price can be considered as one of the most important factors influencing a buyer's decision to purchase (Hustic \& Gregurec, 2015). Because online shopping allows consumers to easily compare prices and save a lot of money, it encourages them to choose their purchasing behaviour through social media.

Product variety refers to a wide range of items that encourages better comparison and, as a result, a better purchase decision (Keeney, 1999). According to the research, online consumers 
International Journal of Entrepreneurship, Business and Creative Economy (IJEBCE), Vol. 2(1), 23-36

Impact of Social Media On Consumer Purchase Behaviour During COVID-19 Pandemic

Lim Kah Boon, Sook Fern Yeo, Cheng Ling Tan, Wong Wei Wen

have a more positive perception of the product variety of online shopping than non-online shopping consumers (Sin \& Tse, 2002). Another significant study discovered that when products were organised into more subcategories in the choice menu, consumers saw that the social network sites offered a more significant assortment of products and experienced greater shopping delight, which improved their purchasing behaviour toward the social media (Chang, 2011).

Risk refers to consumers' perceptions of vulnerability and unfavourable outcomes from participating in activities (Mahliza, 2020). The level of risk that consumers believe is associated with purchasing a product from a specific seller is also indicated by risk (Mahliza, 2020). The study looked at a few specific investigations with regard to the predecessors of social media platforms and concluded that risk had a negative effect on consumers' purchase behaviour via social media (Chang et al., 2005). Furthermore, the researcher asserted that there is a negative relationship between risk and consumer purchasing behaviour via social media platforms (Clemeset al., 2014). However, our result revealed that risk has a significant positive relationship with consumer purchasing behaviour via social media.

\section{CONCLUSION}

The main objective of conducting this research is to enhance the understanding of consumers' purchase behaviour via social media, especially during the COVID-19 pandemic. Furthermore, it also can identify the relationship between the independent variable, which include price, convenience, product variety, and risks. The dependent variable is consumers' purchase behaviour through social media. Our analysis result showed that all of the four independent variables have a significant relationship towards consumer purchase behaviour via social during the COVID-19 pandemic outbreak.

In conclusion, the main contribution of this research is contributing to the knowledge about the impact of the COVID-19 pandemic on consumers' purchase behaviour through social media. This knowledge is for the seller on social media platforms can ultimate and understand the features and the advantage of social media marketing. Other than that, researchers can understand the purchase behaviour of consumers and the factors affecting consumer behaviour. Social media plays an important role in affecting consumers' purchase behaviour. For future research, researchers are advised to study other variables in the questionnaire. This will benefit the other researchers or sellers who can understand more clearly the consumer's purchase behaviour. They can then come out with a better strategy to satisfy the consumers. For future research, researchers are encouraged to extend this study by including other variables such as service quality, subjective norms, etc., to investigate their relationship towards consumer purchase behaviour via social media.

\section{REFERENCES}

Akbar, S. and James, P.T., 2014. Consumers' attitude towards online shopping Factors influencing employees of crazy domains to shop online. Journal of Management and Marketing Research, 14, p.1.

Beneke, J., Scheffer, M.K. and Du, W., 2010. Beyond price-An exploration into the factors that drive young adults to purchase online. International Journal of Marketing Studies, 2(2), p.212.

Bakos, J.Y., 1997. Reducing buyer search costs: Implications for electronic marketplaces. Management science, 43(12), pp.1676-1692.

Bhatnagar, A., Misra, S. and Rao, H.R., 2000. On risk, convenience, and Internet shopping behavior. Communications of the ACM, 43(11), pp.98-105.

Bhatti, A., Akram, H., Basit, H.M., Khan, A.U., Raza, S.M. and Naqvi, M.B., 2020. E-commerce trends during COVID-19 Pandemic. International Journal of Future Generation Communication and Networking, 13(2), pp.1449-1452. 
International Journal of Entrepreneurship, Business and Creative Economy (IJEBCE), Vol. 2(1), 23-36 Impact of Social Media On Consumer Purchase Behaviour During COVID-19 Pandemic Lim Kah Boon, Sook Fern Yeo, Cheng Ling Tan, Wong Wei Wen

Cases, A.S., 2002. Perceived risk and risk-reduction strategies in Internet shopping. The International Review of Retail, Distribution and Consumer Research, 12(4), pp.375-394.

Chang, C., 2011. The effect of the number of product subcategories on perceived variety and shopping experience in an online store. Journal of Interactive Marketing, 25(3), pp.159-168.

Chang, M.K., Cheung, W. and Lai, V.S., 2005. Literature derived reference models for the adoption of online shopping. Information \& management, 42(4), pp.543-559.

Chiang, K.P. and Dholakia, R.R., 2003. Factors driving consumer intention to shop online: an empirical investigation. Journal of Consumer Psychology, 13(1-2), pp.177-183.

Childers, T.L., Carr, C.L., Peck, J. and Carson, S., 2001. Hedonic and utilitarian motivations for online retail shopping behavior. Journal of retailing, 77(4), pp.511-535.

Chin, W.W., 1998. Commentary: Issues and opinion on structural equation modeling.

Cho, J., 2004. Likelihood to abort an online transaction: influences from cognitive evaluations, attitudes, and behavioral variables. Information \& Management, 41(7), pp.827-838.

Clemes, M.D., Gan, C. and Zhang, J., 2014. An empirical analysis of online shopping adoption in Beijing, China. Journal of Retailing and Consumer Services, 21(3), pp.364-375.

Comegys, C., Hannula, M. and Väisänen, J., 2006. Longitudinal comparison of Finnish and US online shopping behaviour among university students: The five-stage buying decision process. Journal of Targeting, Measurement and Analysis for Marketing, 14(4), pp.336-356.

Darian, J.C., 1987. In-home shopping: are there consumer segments? Journal of retailing.

Darley, W.K., Blankson, C. and Luethge, D.J., 2010. Toward an integrated framework for online consumer behavior and decision making process: A review. Psychology \& marketing, 27(2), pp.94-116.

Delafrooz, N., Paim, L.H., Haron, S.A., Sidin, S.M. and Khatibi, A., 2009. Factors affecting students attitude toward online shopping. African Journal of Business Management, 3(5), pp.200-209.

ElMaraghy, H., Schuh, G., ElMaraghy, W., Piller, F., Schönsleben, P., Tseng, M. and Bernard, A., 2013. Product variety management. Cirp Annals, 62(2), pp.629-652.

Guo, Y.U.E. and Barnes, S.J., 2012. Explaining purchasing behavior within World of Warcraft. Journal of Computer Information Systems, 52(3), pp.18-30.

Gold, A.H., Malhotra, A. and Segars, A.H., 2001. Knowledge management: An organizational capabilities perspective. Journal of management information systems, 18(1), pp.185-214.

Goldsmith, R.E. and Flynn, L.R., 2005. Bricks, clicks, and pix: apparel buyers' use of stores, internet, and catalogs compared. International Journal of Retail \& Distribution Management.

Hanaysha, J.R., 2018. An examination of the factors affecting consumer's purchase decision in the Malaysian retail market. PSU Research Review.

Haque, A., Anwar, N., Yasmin, F., Sarwar, A., Ibrahim, Z. and Momen, A., 2015. Purchase intention of foreign products: A study on Bangladeshi consumer perspective. Sage Open, 5(2), p.2158244015592680.

Hair Jr, J.F., Hult, G.T.M., Ringle, C. and Sarstedt, M., 2016. A primer on partial least squares structural equation modeling (PLS-SEM). Sage publications.

Hair Jr, J. F., Sarstedt, M., Hopkins, L., \& Kuppelwieser, V. G. (2014). Partial least squares structural 
International Journal of Entrepreneurship, Business and Creative Economy (IJEBCE), Vol. 2(1), 23-36 Impact of Social Media On Consumer Purchase Behaviour During COVID-19 Pandemic Lim Kah Boon, Sook Fern Yeo, Cheng Ling Tan, Wong Wei Wen

equation modeling (PLS-SEM): An emerging tool in business research. European business review.

Hoch, S.J., Bradlow, E.T. and Wansink, B., 1999. The variety of an assortment. Marketing Science, 18(4), pp.527-546.

Hussain, S., Li, Y. and Li, W., 2021. Influence of platform characteristics on purchase intention in social commerce: Mechanism of psychological contracts. Journal of theoretical and applied electronic commerce research, 16(1), pp.1-17.

Hustic, I. and Gregurec, I., 2015. The influence of price on customer's purchase decision. In Central European conference on information and intelligent systems (p. 27). Faculty of Organization and Informatics Varazdin.

Jarvenpaa, S.L. and Todd, P.A., 1996. Consumer reactions to electronic shopping on the World Wide Web. International Journal of electronic commerce, 1(2), pp.59-88.

Joschka, M., 2021. Malaysia: social media penetration 2021 | Statista. [online] Statista. Available at: <https://www.statista.com/statistics/883712/malaysia-social-media-penetration/> [Accessed 10 June 2021].

Keeney, R.L., 1999. The value of Internet commerce to the customer. Management science, 45(4), pp.533-542.

Kim, H.W., Sumeet, G. and Li, H., 2005, July. Different effects of perceived price and risk on purchase intention for potential and repeat customers. In Pacific Asia Conference on Information Systems (PACIS) (pp. 1639-1645).

Kohli, C., Suri, R. and Kapoor, A., 2015. Will social media kill branding?. Business Horizons, 58(1), pp.35-44.

Kotler, P. and Armstrong, G., 2016. Principles of Marketing Sixteenth Edition: Global Edition. England: Pearson Education Limited.

Lay-Yee, K.L., Kok-Siew, H. and Yin-Fah, B.C., 2013. Factors affecting smartphone purchase decision among Malaysian generation Y. International Journal of Asian Social Science, 3(12), pp.24262440 .

Lee, M.K. and Turban, E., 2001. A trust model for consumer internet shopping. International Journal of electronic commerce, 6(1), pp.75-91.

Lewicki, R.J. and Bunker, B.B., 1995. Trust in relationships: A model of development and decline. Jossey-Bass/Wiley.

Lin, Y.C., Lee, Y.C., Lin, C.H. and Lin, W.T., 2009. Discount level, promotional type, and brand awareness on consumers' brand evaluation and purchase intention: an empirical study of handsets. Soochow Journal of Economics and Business, 67, pp.1-46.

Lin, Y.C., Lee, Y.C. and Chen, K.C., 2012. The influence of brand image and product knowledge in the advertising effect-take placement marketing movie as an example. Journal of Statistics and Management Systems, 15(4-5), pp.581-600.

Liu, C., Marchewka, J.T., Lu, J. and Yu, C.S., 2005. Beyond concern-a privacy-trust-behavioral intention model of electronic commerce. Information \& Management, 42(2), pp.289-304.

Lohse, G., Bellman, S. and Johnson, E.J., 2000. Consumer buying behavior on the Internet: Findings from panel data. Journal of interactive Marketing, 14(1), pp.15-29.

Mahliza, F., 2020. Consumer trust in online purchase decision. EPRA International Journal of 
International Journal of Entrepreneurship, Business and Creative Economy (IJEBCE), Vol. 2(1), 23-36

Impact of Social Media On Consumer Purchase Behaviour During COVID-19 Pandemic Lim Kah Boon, Sook Fern Yeo, Cheng Ling Tan, Wong Wei Wen

Multidisciplinary Research (IJMR), 6(2), pp.142-149.

Mallapragada, G., Chandukala, S.R. and Liu, Q., 2016. Exploring the effects of "What"(product) and "Where"(website) characteristics on online shopping behavior. Journal of Marketing, 80(2), pp.21-38.

Meuter, M.L., Ostrom, A.L., Roundtree, R.I. and Bitner, M.J., 2000. Self-service technologies: understanding customer satisfaction with technology-based service encounters. Journal of marketing, 64(3), pp.50-64.

Mirabi, V., Akbariyeh, H. and Tahmasebifard, H., 2015. A study of factors affecting on customers purchase intention. Journal of Multidisciplinary Engineering Science and Technology (JMEST), 2(1).

Rahim, A., Safin, S.Z., Kheng, L.K., Abas, N. and Ali, S.M., 2016. Factors influencing purchasing intention of smartphone among university students. Procedia Economics and Finance, 37, pp.245-253.

Reibstein, D.J., 2002. What attracts customers to online stores, and what keeps them coming back?

Journal of the academy of Marketing Science, 30(4), pp.465-473.

Rizwan, M., Umair, S.M., Bilal, H.M., Akhtar, M. and Bhatti, M.S., 2014. Determinants of customer intentions for online shopping: A Study from Pakistan. Journal of Sociological Research, 5(1), pp.248-272.

Shimp, T.A. and Bearden, W.O., 1982. Warranty and other extrinsic cue effects on consumers' risk perceptions. Journal of Consumer research, 9(1), pp.38-46.

Sin, L. and Tse, A., 2002. Profiling internet shoppers in Hong Kong: demographic, psychographic, attitudinal and experiential factors. Journal of International Consumer Marketing, 15(1), pp.729.

Surenderkumar, C.V., 2016. A Study On Impact Of Social Media Marketing On Consumer Buying Behavior With Reference To Thane District. Shri Jagdish Prasad Jhabarmal Tibrewala University, pp.1-352. Swaminathan, V., Lepkowska-White, E. and Rao, B.P., 1999. Browsers or buyers in cyberspace? An investigation of factors influencing electronic exchange. Journal of computer-mediated communication, 5(2), p.JCMC523.

Szymanski, D.M. and Hise, R.T., 2000. E-satisfaction: an initial examination. Journal of retailing, 76(3), pp.309-322.

y Monsuwé, T.P., Dellaert, B.G. and De Ruyter, K., 2004. What drives consumers to shop online? A literature review. International journal of service industry management.

Yoon, S., Oh, S., Song, S., Kim, K.K. and Kim, Y., 2014. Higher quality or lower price? How valueincreasing promotions affect retailer reputation via perceived value. Journal of Business Research, 67(10), pp.2088- 2096. 